\title{
RANCANG BANGUN REGULASI \\ PENYELENGGARAAN UMRAH BERBASIS MASLAHAT
}

\author{
Firman Muhammad Arif \\ IAIN Palopo \\ firmanarif@iainpalopo.ac.id
}

\begin{abstract}
Abstrak
Regulasi penyelenggaraan umrah memerlukan rancang bangun secara komprehensif dan menyeluruh. Penanganan anomali umrah yang dilakukan beberapa oknum biro travel penyelenggara terkesan lamban karena ditangani dengan cara hukum dan bukan dengan cara politis. Dalam tulisan ini, maslahat menjadi instrumen penting dalam melakukan rancang bangun regulasi penyelenggaraan umrah yang memprioritaskan nilai dan konsep istislahi dan sadd al zari'ah yang keduanya diviralkan dalam berbagai literatur perumusan hukum Islam. Kebijakan istislahi dan sadd al zari'ah dijadikan sebagai barometer dalam meramu desain regulasi penyelenggaraan ibadah umrah sehingga regulasi yang dihasilkan dapat diterima masyarakat luas, minim kontroversi, sepenuh hati memberi proteksi dan kenyamanan. Produk regulasi penyelenggaraan ibadah umrah dinilai telah terintegrasi dengan konsep atau nilai istislahi dan sadd al zari'ah karena dirumuskan oleh ulama pewaris nabi sebagai generasi terpelajar yang patut dan pantas dipedomani hingga sekarang.
\end{abstract}

Kata Kunci:

Regulasi; Rancang Bangun; Penyelenggaraan Umrah; Maslahat

\begin{abstract}
Umrah regulation requires a comprehensive and thorough design. The handling of the anomaly of Umrah carried out by some of the organizer's travel agencies seemed sluggish because it handled by law and not by political means. In this paper, principles become an important instrument in the design of the regulation of the implementation of Umrah that prioritizes the values and concepts of Istislahi and Sadd Al Zari'ah which both are tolerated in various Islamic law literature. The policy of Istislahi and Sadd al Zari'ah serves as a measuring instrument in the design of the regulation of Umrah worship so that the resulting regulation can be accepted by the wider community, minimal controversy, wholeheartedly give protection and comfort. The product of the regulation of Umrah worship is assessed to be integrated with the concept or value of Istislahi and Sadd Al
\end{abstract}


Zari'ah because it is formulated by the Prophet's hair as a well-known generation who deserves and deserve are until now.

Keywords:

Regulation; Design; Organization of Umrah; Maslahat

\section{A. PENDAHULUAN}

alah satu bagian haji adalah umrah dan kualitas haji muslim tidak akan menjadi sempurna dan sah bila tidak diiringi dengan ritual umrah. Independensi penyelenggaraan umrah dari ibadah haji tetap berpedoman pada tuntunan agama sebagai ibadah yang diidam-idamkan oleh umat Islam. ${ }^{1}$ Bagi seorang mukallaf yang melaksanakan haji dan umrah sama halnya meniti jalan hidup yang berdimensi 'ubudiyyah (kebaktian), ruhiyyah (spiritual) dan insaniyyah (kemanusiaan) sehingga patut dinilai sebagai mukallaf (subyek) yang meneladani napak tilas kehidupan Rasulullah sallahu 'alaihi wasallam. ${ }^{2}$

Kebijakan manajemen haji di Indonesia tidak pernah terpisahkan dari kebijakan politik Saudi Arabia dalam aspek pengelolaan dan kuota jamaah. Tahun 2013 terjadi pemangkasan jatah kuota haji dari seluruh dunia sebesar 20\% dengan alasan pembenahan infrastruktur. ${ }^{3}$ Pada masa Jokowi-JK, seiring dengan selesainya konstruksi dan modifikasi infrastruktur maka kuota tersebut ditambah menjadi 230 ribu namun tidak memangkas secara signifikan antrian calon jamaah haji. Alasan utamanya adalah animo umat mengalami grafik peningkatan yang cukup fantastis dari tahun ke tahun. ${ }^{4}$

Ketidakselarasan jumlah pendaftar dan kuota haji yang tersedia diiringi pertimbangan faktor usia, minimnya peluang keberangkatan dan antrian menunggu menjadikan ibadah umrah sebagai opsi alternatif walaupun secara syar'i tidak dapat menggugurkan kewajiban melaksanakan haji wajib gairu fauriy (kewajiban yang tidak mesti disegerakan). ${ }^{5}$ Dalam khazanah fikih Islam, kategori ibadah salat dan puasa wajib fawriy (wajib disegerakan), dan zakat sebagai kewajiban yang disegerakan saat muslim mencapai batas wajib zakat. ${ }^{6}$

${ }^{1}$ Lihat, al Sayyid al Syahid, al Khitab al Islamiy wa al 'Adalah bi al Akhar (al Qahirah; Wizarah al Awqaf Misr, 1423 H/2002 M), h. 97. Lihat pula, Sayyid Sabiq, Fiqh al Sunnah Mujallad al Awwal (al-Qahirah: Dar al-Fath li al-I'lam al-'Arabiy, 1998 M/1417 H), h. 542.

${ }^{2}$ Lihat, Abbas Mahmud al-'Aqqad, al Islam Da'wah 'Alamiyyah (al-Qahirah: Maktabah al Usrah, 1999 M), h. 103.

${ }^{3}$ Lihat, Subkhani Kusuma Dewi, "Trend Wisata Umrah: Antara Meneladani Sunnah dan Turisme Spiritual”, Empirisma Volume 26 Nomor 2 Juli Tahun 2017, h. 193

${ }^{4}$ Lihat, Firman Muhammad Arif, "Penyelenggaraan Ibadah Umrah Berbasis Maslahat", al-Amwal Edisi Maret Nomor 1 Tahun 2019. Lihat pula, Kholilirrahman, "Hajinya Lansia Ditinjau dari Perspektif Bimbingan dan Konseling Islam", Jurnal al-Balagh Jurnal Dakwah dan Komunikasi IAIN Surakarta Volume 2 No. 2, Juli Desember 2017, h. 232.

5 Akhmad Anwar Dani, "Problematika Pengelolaan Penyelenggaraan Umrah di Kota Surakarta", Ilmu Dakwah: Academic Journal for Homiletic Studies Volume 12 Nomor 1, 2018 UIN Sunan Gunung Djati, h. 24

${ }^{6}$ Lihat, Sayyid Sabiq, Fiqh al Sunnah Mujallad al Awwal, h. 542. 
Pangsa pasar industri pariwisata umrah secara masif mengalami peningkatan kebutuhan sehingga produsen jasa pelayanan umrah juga mengalami peningkatan yang signifikan. Umrah tidak hanya diposisikan sebagai ibadah ubudiyyah tetapi telah dieskalasi ke rating kebutuhan industri yaitu penjualan jasa berbasis profit. Kondisi tersebut mengindikasikan bahwa umrah adalah komoditas yang dapat diperjual belikan, menjanjikan dan menguntungkan. ${ }^{7}$

Ekspektasi pendapatan nasional akan terwujud jika pemerintah memposisikan diri secara intensif dan serius. Dengan asumsi rata-rata biaya umrah sekitar 20 jutaan/orang maka pembiayaan terbesar lebih $80 \%$ diserap untuk hunian hotel, penerbangan, dan sisanya digunakan untuk hal-hal pendukung. ${ }^{8}$ Potensi sebesar 7,2 triliun/tahun dimobilisasi dengan memperkuat dan meregulasikan pemakaian maskapai penerbangan nasional yang berpotensi meningkatkan pendapatan Badan Usaha Milik Negara. Selama ini potensi tersebut berdampak pada maskapai Timur Tengah yang secara agresif melirik industri umrah di tanah air apalagi Arab Saudi menggelontorkan 1,5 juta visa untuk umrah sejak tahun $2016 .{ }^{9}$

Namun di balik potensi ekonomi dalam jasa umrah, terdapat ancaman yang sarat dengan horror topic bahkan menjadi terror topic di tahun 2016 hingga 2018. Kejahatan industri jasa umrah menjelma dalam wujud trending topic. Kasus First Travel tahun 2017 terbukti telah melakukan penipuan dana jamaah dengan kerugian yang fantastis. ${ }^{10}$ Biro Travel Rihlah Alatas Wisata di Jawa Tengah dengan tindakan penipuan yang sama terhadap calon jamaah yang kerugiannya ditaksir sekitar 500 juta rupiah. ${ }^{11}$ Biro Abu Tours Makassar juga mengalami hal yang sama dan Januari 2019 telah divonis karena terbukti melakukan pencucian uang sebesar 1,2 triliun rupiah dan menelantarkan jamaah. ${ }^{12}$ Penanganan kepolisian terkait dengan kasus tindak pidana umrah dengan dakwaan penipuan yang didasarkan dari KUHP saja yaitu Pasal 378 jo Pasal 65 (1). Regulasi haji dan umrah diatur UU Nomor 13 Tahun 2008 tentang Penyelenggaraan Ibadah Haji yang didalamnya mengatur ketentuan pidana dalam pelanggaraan terhadap UU tersebut. ${ }^{13}$

${ }^{7}$ Lihat, Subkhani Kusuma Dewi, "Trend Wisata Umrah: Antara Meneladani Sunnah dan Turisme Spiritual", Empirisma Volume 26 Nomor 2 Juli Tahun 2017, h. 194.

8 Affan Rangkuti, Industri Umrah Berpotensi Sumbang 7,2 Triliun, diakses via republika.co.id pada tanggal 17 April 2019.

9 Aqwam Fiazmi Hanifan, Komersialisasi Umrah Ketika Ibadah Bernilai Bisnis, diakses dari komersialisasi-umrah-ketika-ibadah-bernilai-bisnis-Dl pada tanggal 17 April 2019.

${ }^{10}$ Lihat, Edi Hidayat, Korban First Travel yang Belum Diberangkatkan Mencapai 58.682 orang, diakses nasional.kompas.com pada tanggal 17 Mei 2019.

${ }^{11}$ Lihat, Gunawan, Dicatut Penipu, Direktur Biro Travel Haji dan Umrah Merugi 500 jutaan, diakses news.detik.com pada tanggal 17 Mei 2019.

12 Tim Jurnalis Detik.com, Fakta-fakta Mengejutkan dalam Persidangan CEO Abu Tours, diakses https://news.detik.com/ pada tanggal 21 April 2019.

${ }^{13}$ Lihat, Sigit Prihanto, "Penegakan Hukum terhadap Tindak Pidana Penipuan Calon Jamaah Umrah", Jurnal Hukum Khaira Ummah Vol. 12 No. 4 Desember 2017, h. 886. 


\section{B. METODE PENELITIAN}

Tulisan ini berkaitan dengan desain bangunan penyelenggaraan ibadah umrah berbasis maslahat. Penelitian ini adalah penelitian kualitatif mengelaborasi teknik atau metode studi pengembangan hukum melalui pendekatan yuridis empiris (pendekatan kenyataan hukum dalam masyarakat) ${ }^{14}$ dan bersifat preskriptif supling. Penelitian preskriptif supling adalah penelitian yang memberikan penilaian terhadap sistem regulasi penyelenggaraan umrah secara nasional. Dalam praktiknya, tulisan ini bertujuan untuk menilai dinamika hukum yang menjadi objek pada pokok masalah yang berkenaan dengan penyelenggaraan umrah. ${ }^{15}$

Penelitian ini, membahas kecermatan studi perkembangan hukum menjadi ukuran dan komparasi antara hukum yang telah diwujudkan perihal penyelenggaraan umrah. ${ }^{16}$ Pendekatan yang digunakan adalah pendekatan normatif dan beberapa kaidah-kaidah fikih sekunder setelah Alquran dan Hadis untuk mendapatkan jawaban yang realistis dan sesuai dengan syari'ah. ${ }^{17}$

Perkembangan regulasi penyelenggaraan umrah di Indonesia meniscayakan terjadinya proses dan perubahan guna memberikan pelayanan dan menegakkan hukum terpadu bagi masyarakat Islam. ${ }^{18}$ Sejarah perkembangan hukum di dalam tulisan ini adalah konsep yang mengkaji dan memaparkan regulasi penyelenggaraan umrah sebagai hukum positif pada masa tertentu hingga terkini. ${ }^{19}$

Preferensi regulasi penyelenggaraan umrah selalu mengarah kepada pengaturan, pembinaan, dan pengendalian mengindikasikan adanya keberadaan hukum dan karakter produk hukum yang senantiasa berubah sejalan dengan perkembangan sosial. ${ }^{20}$ Begitupun eksistensi maslahat yang membentuk konfigurasi eksak, di mana maslahat ditegakkan dan diterapkan berarti hukum Allah telah diterapkan di dalamnya. ${ }^{21}$

Tulisan ini memposisikan nilai-nilai maslahat di garda terdepan dalam proses modernisasi dan perubahan sosial yang sejalan dengan hukum sebagai alat untuk mengubah keadaan dan memerankan sosial kontrol. Fungsi regulasi dipertimbang

${ }^{14}$ Zainuddin Ali, Sosiologi Hukum (Cet. VII; Jakarta: SInar Grafika, 2012), h. 14.

${ }^{15}$ Indah Fitriana Sari, "Tinjauan Hukum Islam terhadap Pembiayaan Haji dan Umrah Melalaui Sistem Marketing di PT. Arminareka Perdana Yogyakarta”, Jurnal Economic: Ekonomi dan Hukum Islam Vol. 5 No. 1 tahun 2015, h. 93.

${ }^{16}$ Lihat, Riduan Syahrani, Intisari Ilmu Hukum (Cet. VI; Bandung: Citra Aditya Bakti, 2013), h.222

${ }^{17}$ Kartajaya Hermawan \& Sula Muhammad Syakir, Syariah Marketing (bandung: PT Mizan Pustaka, 2006), h. 12. Lihat pula, Indah Fitriana Sari, “Tinjauan Hukum Islam terhadap Pembiayaan Haji dan Umrah Melalaui Sistem Marketing di PT. Arminareka Perdana Yogyakarta”, h. 93.

${ }^{18}$ Lihat, Peter Mahmud Marzuki Penelitian Hukum (Cet. VIII; Jakarta: Kencana Prenada Media Group, 2013), h. 166

${ }^{19}$ Lihat, Donald Black, Sociological Justice (New York: Academic Press, 1989), h. 21.

${ }^{20}$ Moh. Mahfud MD, Politik Hukum di Indonesia (Cet. V; Jakarta: RajaGrafindo Persada, 2012), h. 344.

21 Lihat, Dewan Syariah Nasional MUI, Himpunan Fatwa DSN MUI, Keputusan No. 28/DSNMUI/III/2002, diterbitkan atas kerjasama MUI dengan Bank Indonesia, Edisi II, tahun 2002, h. 173. Lihat pula, Djazuli, Kaidah-Kaidah Fikih-Kaidah-Kaidah Hukum Islam dalam Menyelesaikan Masalah-masalah yang Praktis (Cet. III; Jakarta: Kencana Prenada Media, 2010), h. 77 \& 166. 
kan karena membahas perubahan hukum dan efektivitas pemberlakuan dalam masyarakat. ${ }^{22}$

Hukum adalah gejala sejarah yang mempunyai sejarah dan dinamika. Gejala sejarah berarti tunduk pada pertumbuhan yang terjadi terus menerus. Rumusan mengenai pertumbuhan memuat 2 (dua) arti, yaitu unsur perubahan dan unsur stabilitas. ${ }^{23}$ Mempelajari hukum secara ilmu pengetahuan harus terarah dengan mengeksplorasi dinamika atau proses yang terjadi didalamnya. ${ }^{24}$ Regulasi penyelenggaraan umrah sebagai gejala masyarakat tidak berdiri sendiri dan saling berhubungan. Perkembangan usaha biro travel ibadah umrah, perubahan bentuk, dan pencabutan operasi biro travel umrah ditentukan dengan berbagai faktor yang bersumber dari keresahan masyarakat, faktor ekonomi, politik, agama, dan susila. ${ }^{25}$

Kenyataan hukum di dalam kehidupan sosial kemasyarakatan bukan kenyataan dari bentuk pasal-pasal dalam perundang-undangan, melainkan sebagaimana hukum itu dioperasikan oleh masyarakat dalam kehidupan sehari-hari. Jika mempelajari hukum dengan realitas yang demikian maka harus keluar dari batas-batas regulasi penyelenggaraan ibadah umrah dan aturan yang saling terkait dengan mengamati praktik-praktik dan/atau hukum sebagaimana yang dilakukan oleh orang-orang di dalam masyarakat. Pengkajian hukum yang seperti ini disebut dengan pendekatan yuridis empiris. ${ }^{26}$

Logika dan penalaran hukum mengenai penyelenggaraan umrah dinilai patut untuk dielaborasi dan ditelaah secara memadai sehingga terwujud pemahaman yang komprehensif, pemakluman yang konstruktif, kritis, rasional, argumentasi teori, rumusan undang-undang, opini, dan pendapat hukum. ${ }^{27}$ Penalaran hukum dalam menganalisa hukum dan regulasi perlu diajarkan supaya terkesan membumi dan memungkinkan untuk dipelajari konkret, abstrak, rasional atau logisnya.

\section{DINAMIKA PENYELENGGARAAN IBADAH UMRAH}

Historisitas penyelenggaraan umrah tidak bisa dilepaskan dari ibadah haji. Sejak masa kolonial Belanda, kemerdekaan, Orde Lama dan Orde Baru, penyelenggaran ibadah umrah sudah sepaket dengan ibadah haji dan belum marak dijalankan di luar dari musim haji. Penyelenggaraan ibadah umrah di luar dari musim haji sudah diselenggarakan di masa reformasi namun belum semasif di tahun 2016 hingga sekarang. Dalam arti lain, independensi penyelenggaraan umrah sebelum reformasi masih minim peminat dibandingkan dengan penyelenggaraan umrah di era reformasi. Regulasi tentang umrah mulai dirintis dengan adanya

${ }^{22}$ Zainuddin Ali, Sosiologi Hukum, h. 41.

${ }^{23}$ Van Apeidom, Inleiding Tot de Stude Van Het Nederlandse Recht, diterjemahkan oleh M. Oetarid Sadino dengan judul: Pengantar Ilmu Hukum (Jakarta: Noordhoff-Kolff, 1959), h. 335.

${ }^{24}$ Lihat, Riduan Syahrani, Intisari Ilmu Hukum, h. 222.

${ }^{25}$ Van Apeidom, Inleiding Tot de Stude Van Het Nederlandse Recht, h. 222

${ }^{26}$ Zainuddin Ali, Sosiologi Hukum (Cet. VII; Jakarta: SInar Grafika, 2012), h. 13.

${ }^{27}$ Lihat, Urbanus Ura Weruin, "Logika, Penalaran, Argumentasi Hukum", Jurnal Konstitusi Volume 14 Nomor 2, Juni 2017, h. 377. 
Keputusan Menteri Agama Nomor 396 Tahun 2003 tentang Penyelenggaraan Ibadah Haji Dan Umrah. ${ }^{28}$

Keberadaan Panitia Perbaikan Perjalanan Haji Indonesia di Orde Lama merupakan bentuk baru dari Komite Perbaikan Haji Indonesia sudah ada sejak masa kolonial. Penguatan PPHI dilegitimasi oleh SK Menteri Agama KH. Wahid Hasyim, anak dari pencetus Resolusi Jihad KH. Hasyim Asy'ari tanggal 6 Februari 1950 dan 9 Februari 1950 ditunjuk sebagai satu-satunya wadah yang mengurus dan menyelenggarakan perjalanan haji. Legalitas PPHI diperkuat sehingga semua urusan haji dikoordinasi oleh Kementerian Agama dengan totalitas tanggung jawab penyelenggaraan dan wewenang menteri terkait yang selanjutnya dibentuk PT. Pelayaran Muslim sebagai solusi untuk menyelesaikan administrasi dan pelayanan jamaah saat itu. ${ }^{29}$

Tahun 1999, ditetapkan UU Nomor 17 Tahun 1999 tentang Penyelenggaraan Ibadah Haji yang memandatkan tugas pelayanan, pembinaan, dan perlindungan bagi jamaah haji. Tahun 1999, kuota haji dibagi menjadi dua: Haji Reguler (pemerintah) dan Haji Khusus (swasta). ${ }^{30}$ UU Nomor 17 Tahun 1999 disempurnakan dengan ditetapkannya UU Nomor 13 Tahun 2008 melalui SISKOHAT. ${ }^{31}$ Tahun 2013, peluncuran SISKOHAT generasi kedua dan pemotongan kuota haji sebesar 20\% sebagai dampak proyek perluasan Masjid Haram dan migrasi biaya penyelenggaraan haji dari bank konvensional ke bank syariah. Tahun 2014, ditetapkannya UU Nomor 34 Tahun 2014. ${ }^{32}$

Sebelum tahun 2014, keberangkatan umrah jarang terjadi karena ibadah umrah masih didominasi oleh kalangan menengah atas dan kalangan ekonomi bawah dinilai tidak atau kurang berminat. Adapun problematika umrah dengan berbagai modus penipuan menurut Menteri Agama Lukman Hakim Saifuddin mulai terendus sejak 6 tahun terakhir atau sejak 2014. ${ }^{33}$ Maraknya manipulasi penyelenggaraan umrah dalam 5-6 tahun terakhir atau sebelum 2019 tidak lain karena keterbatasan kuota haji dan besarnya animo kalangan ekonomi bawah.

Keterbatasan kuota haji yang diiringi dengan animo masyarakat muslim berimbas pada lamanya daftar antrian haji sehingga banyak kalangan ekonomi bawah menempuh opsi dengan beribadah umrah. Ketika kalangan ekonomi atas yang beribadah umrah maka masalah dalam penyelenggaraan umrah jarang terjadi

${ }^{28}$ Kementerian Agama RI, PMA No. 396 Tahun 2003 tentang Penyelenggaraan Ibadah Haji dan Umrah.

${ }^{29}$ Sumuran Harahap, Lintasan Haji Indonesia (Jakarta: Intermedia, 1994). Lihat, Mahrus Sali, Catatan Penyelenggaraan haji dari Masa ke Masa, artikel online diakses iphi.web.id pada tanggal 17 Mei 2019. Lihat pula, Redaksi Republika, Pengelolaan Haji pada Masa Orde Lama, diakses republika.co.id pada tanggal 17 Mei 2019.

${ }^{30}$ Republik Indonesia, Undang-Undang No. 17 Tahun 1999 tentang Penyelenggaraan Ibadah Haji Bab XII Pasal 23. Regulasi menetapkan pemberlakukan paspor haji dan bukan paspor yang berwarna hijau.

${ }^{31}$ Republik Indonesia, Undang-Undang No. 13 Tahun 2008 tentang Penyelenggaraan Ibadah Haji, Bab XII Pasal 38-42.

${ }^{32}$ Sumuran Harahap, Lintasan Haji Indonesia (Jakarta: Intermedia, 1994), h. 77

${ }^{33}$ Lihat, Lukman Hakim Saifuddin, Kemenag Ungkap Penyebab Penipuan Umrah Marak di 6 Tahun Terakhir, diakses detik.com pada tanggal 19 Mei 2019. 
atau relatif minim persoalan sebab kalangan menengah atas cenderung edukatif dan sulit dijadikan objek penipuan. Namun ketika antrian pemberangkatan haji dinilai cukup panjang maka beberapa kalangan ekonomi atas menilai bahwa penyelenggaraan ibadah umrah bisa menjelma menjadi potensi lahan bisnis yang menggiurkan.

Terdapat 6 asosiasi penyelenggara haji dan umrah yang berperan aktif dalam pembinaan perusahaan biro perjalanan haji dan umrah. ${ }^{34}$ Berikut asosiasi penyelenggara haji dan umrah yang ada di Indonesia:

1. Himpunan Penyelenggara Haji dan Umrah disingkat HIMPUH pada tahun 2009, menaungi 313 travel haji khusus dan umrah dari seluruh Indonesia. ${ }^{35}$

2. Asosiasi Muslim Penyelenggara Haji dan Umrah Republik Indonesia disingkat Amphuri, lahir dari tiga gabungan asosiasi atas arahan Menteri Agama Maftuh Basyuni yang disingkat AMPUH (Asosiasi Muslim Penyelenggara Haji dan Umrah), SEPUH (Serikat Penyelenggara Umrah dan Haji) dan AMPPUH (Asosiasi Muslim Perusahaan Penyelenggara Umrah dan Haji) yang resmi dideklarasikan 1 September 2007 yang mewadahi 100 perusahaan travel haji dan umrah seluruh Indonesia. ${ }^{36}$ Memiliki bargaining power dalam bernegosiasi dengan muassasah di Saudi dan stake holder lainnya. Bersertifikat ISO 9001:2008 Sistem Manajemen Mutu dan menerapkan tata kelola organisasi yang hingga kini memiliki delapan Dewan Perwakilan Daerah (DPD).

3. Asosiasi Penyelenggara Haji Umrah Indonesia disingkat Asphurindo, dikukuhkan kembali dengan putusan PTUN tanggal 24 Januari 2018 setelah pergolakan dualisme kepengurusan.

4. Kesatuan Tour Travel Haji Umrah Republik Indonesia disingkat Kesthuri berdiri 22 Februari 2014 dengan dua DPD di Sulawesi Selatan dan Jawa Barat. Kesthuri adalah asosiasi berbadan hukum. ${ }^{37}$

5. Perkumpulan Travel Umrah dan Haji disingkat Pratama, resmi tahun 2017 dengan SK Kemenkumham 27 Desember 2016 yang hadir sebagai pelengkap dari asosiasi yang ada.

6. Sarikat Penyelenggara Umrah dan Haji Indonesia atau disingkat Sapuhi, didirikan di Jakarta 28 Mei 2018 setelah berinduk di Aphurindo.

Beberapa regulasi/aturan telah dikeluarkan terkait dengan penyelenggaraan ibadah umrah yang selanjutya diikuti dengan berbagai penyempurnaan seperti Keputusan Menteri Agama Nomor 396 Tahun 2003 tentang Perubahan Atas Keputusan Menteri Agama Republik Indonesia Nomor 371 Tahun 2002 tentang

${ }^{34}$ Lihat, PT. Budi Luhur Abadi, 6 Asosiasi Penyelenggara Haji dan Umrah di Indonesia, diakses via ayohaji.com pada tanggal 21 Mei 2019.

${ }^{35}$ Lihat, Himpuh, Profil mengenai Himpunan Penyelenggara Umrah dan Haji Khusus, diakses via himpuh.or.id pada tanggal 21 Mei 2019.

${ }^{36}$ Lihat, Amphuri, Profil mengenai Asosiasi Muslim Penyelenggara Haji dan Umrah Republik Indonesia, diakses via amphuri.org pada tanggal 21 Mei 2019.

37 Kesthuri, Profil Kesatuan Tour Travel Haji Umrah Republik Indonesia, diakses kesthuri.id pada tanggal 21 Mei 2019. 
Penyelenggaraan Ibadah Haji dan Umrah. Selanjutnya diikuti dengan UU Nomor 13 Tahun 2008 tentang Penyelenggaraan Haji dan hanya Peraturan Menteri Agama Nomor 18 Tahun 2015 yang mengatur secara khusus tentang penyelenggaraan perjalanan ibadah umrah.

Keterlibatan pemerintah dalam anomali penyelenggaraan umrah dinilai lebih bernuansa kuratif. ${ }^{38}$ Berikut beberapa kasus gagalnya pemberangkatan puluhan ribu jamaah umrah dibuktikan dengan beberapa data sebagai berikut:

1. Tahun 2015, tercatat jumlah 1610 jemaah umrah yang menjadi korban kasus penipuan haji dan umrah.

2. Tahun 2016, tercatat 290 jemaah yang menjadi korban penipuan.

3. Tahun 2017, tercatat 35.149 jemaah umrah yang gagal diberangkatkan karena kasus penipuan, jemaahnya diterlantarkan, dan refund yang mustahil terwujud..$^{39}$ Kasus First Travel dengan jumlah korban 58 ribu dan hanya mampu memberangkatkan 14 ribu saja dan Abu Tour di Makassar dengan pencucian uang sebesar 1,2 trilun rupiah dan penelantaran jamaah. ${ }^{40}$

\section{SIGNIFIKANSI RANCANG BANGUN REGULASI BERBASIS MASLAHAT}

Dengan maraknya kasus penipuan, penggelapan, dan pencucian dana calon jemaah umrah sejak tahun 2015 hingga awal 2019 maka alasan-alasan hukum digunakan oleh pemangku kebijakan untuk sampai pada putusannya yang terkristalisasi dalam wujud regulasi khusus berkenaan dengan penyelenggaraan umrah. ${ }^{41}$ Anomali penyelenggaraan umrah mirip dengan kasus haji tahun 1969 sehingga pemerintah bersikap egaliter dan mengeluarkan regulasi karena maraknya calon jemaah yang gagal berangkat oleh berbagai badan swasta maka diterbitkanlah Keppres Nomor 22 Tahun 1969. Regulasi tersebut memposisikan pemerintah selaku pemegang penuh semua proses penyelenggaraan ibadah haji. ${ }^{42}$

Menurut Otoritas Jasa Keuangan, literasi keuangan adalah pengetahuan, keterampilan dan keyakinan yang mempengaruhi sikap dan perilaku untuk meningkatkan kualitas pengambilan keputusan dan pengelolaan keuangan untuk mencapai kesejahteraan. ${ }^{43}$ Ketimpangan penyelenggaran umrah berkenaan dengan permasalahan keuangan yang kerap menimpa masyarakat dengan minimnya inklusi

${ }^{38}$ Abdllah, Manajemen Umrah Mengurai Problematika Penyelenggaraan Ibadah Umrah di Indonesia (Cet. I; Makassar: Penerbit Shofia, 2018), h. 10

${ }^{39}$ Novi Ratnawati, Upaya Penaggulangan Terjadinya Penipuan yang Dilakukan Biro Perjalanan Umrah: Studi Kasus Kota Bandar Lampung. Jurnal Hukum Fakultas Hukum Universitas Lampung di Bandar Lampung 2018, h. 3.

40 Tim Jurnalis Detik.com, Fakta-fakta Mengejutkan dalam Persidangan CEO Abu Tours, diakses https://news.detik.com/ pada tanggal 21 April 2019.

${ }^{41}$ Lihat, Peter Mahmud Marzuki, Penelitian Hukum (Cet. VIII; Jakarta: Kencana Prenada Media Group, 2013), h. 158

${ }^{42}$ Republik Indonesia, Undang-Undang No. 17 Tahun 1999 tentang Penyelenggaraan Ibadah Haji Bab XII Pasal 23. Distingsi dari regulasi tersebut menetapkan pemberlakukan paspor haji dan bukan berwarna hijau.

${ }^{43}$ Fajar Sulaiman, Pemahaman tentang Literasi Keuangan, diakses via wartaekonomi.co.id pada tanggal 11 Juni 2019. 
(ketercakupan wawasan) dan literasi keuangan dengan perbandingan 68 : 32. ${ }^{44}$ Data survey OJK tahun 2016, tingkat literasi keuangan Indonesia sebesar 29,7\% artinya dari 100 orang hanya sekitar 30 saja yang memiliki pengetahuan, keterampilan, dan kepercayaan yang memadai mengenai produk dan layanan keuangan. ${ }^{45}$

Tahun 2019 hingga Mei sudah ada pengaduan hingga 254 kasus dan pengaduan tersebut diantaranya adalah jebakan pinjaman online, skimming dalam kejahatan perbankan, aksi manipulasi produk atau layanan keuangan, investasi bodong, akses data pribadi yang berpotensi disalahgunakan, intimidasi terhadap nasabah, bunga yang tinggi dengan kesan mencekik dan termasuk didalamnya anomali penyelenggaraan ibadah umrah meskipun tidak semasif dengan sebelum tahun 2019. ${ }^{46}$

Literasi hukum menurut Mahfud MD bahwa masyarakat cenderung menilai hukum sebagai hal yang rumit, identik dengan teori dan buku-buku tebal sehingga orang cenderung menghindar bahkan hanya untuk menambah wawasan tentang hukum. Rendahnya literasi hukum memicu mudahnya kriminalisasi bagaikan bola salju yang terus bergulir yang berpotensi berdampak kerusakan dalam tatanan kehidupan masyarakat. ${ }^{47}$

Regulasi yang mengatur penyelenggaraan perjalanan ibadah umrah diatur secara independen, selanjutnya dituangkan dalam Peraturan Menteri Agama Nomor 18 Tahun 2015. Dalam catatan Dirjen Penyelenggaraan Haji dan Umrah tahun 2015, terhitung dari 1 Januari sampai dengan April 2015 disebutkan bahwa jumlah jemaah umrah mencapai 21.425 orang. Rata-rata setiap pekan ada sekitar 1.500 jamaah umrah yang berangkat ke Saudi dengan menggunakan 85 unit travel atau Penyelenggara Perjalanan Ibadah Umrah (PPIU). ${ }^{48}$

Model dari regulasi PMA Nomor 18 tahun 2015 digaungkan dalam sosialisasi lima pasti perjalanan umrah sebagai wujud interpretasinya. Regulasi PMA Nomor 18 tahun 2015 memberikan celah, mode dan cara untuk melakukan aksi nyata dari 5-S (lima pasti umrah; (travel, jadwal, terbang, hotel, dan visa) namun tersirat didalamnya modus melakukan kinerja ekonomi "manusia memakan manusia". Realitas tingginya animo masyarakat Islam menjalankan ibadah umrah memungkinkan maraknya oknum biro travel dengan aksi manipulasi, baik dengan

${ }^{44}$ Misbakhun, OJK Larang Masyarakat Cicil Biaya Umrah di Travel, diakses OJK.go.id pada tanggal 10 Juni 2019.

${ }^{45}$ Fajar Sulaiman, Pemahaman tentang Literasi Keuangan, diakses via wartaekonomi.co.id pada tanggal 11 Juni 2019.

${ }^{46}$ Lihat, Novi Ratnawati, "Upaya Penanggulangan Terjadinya Penipuan yang Dilakukan Biro Perjalanan Umrah: Studi Kasus Kota Bandar Lampung”, Jurnal Hukum Fak. Hukum Universitas Lampung di Bandar Lampung Vol. I No. 1 Tahun 2018, h. 10-14. Lihat pula, Misbakhun, OJK Larang Masyarakat Cicil Biaya Umrah di Travel, diakses OJK.go.id pada tanggal 10 Juni 2019.

${ }^{47}$ Lihat, A. Muchaddam Fahham, "Penyelenggaraan Ibadah Umrah: Akar Masalah dan Penanganannya", Info Singkat Kajian Singkat Terhadap Isu Aktual dan Strategis, Pusat Penelitian Badan Keahlian DPR RI Vol. X, No. 07/I/Puslit/April/2018, h. 13-17

${ }^{48}$ Dirjen Penyelenggaraan Haji dan Umrah Kementerian Agama RI , Tingginya Minat Umrah, Kemenag Ingatkan 5 Pasti Umrah ke Publik, diakses haji.kemenag.go.id pada tanggal 12 Juni 2019. 
money game, praktik MLM, skema ponzi, arisan berantai atau cara-cara yang tidak

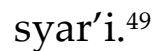

Regulasi PMA Nomor 18 Tahun 2015 tagline 5 pasti umrah (travel, jadwal, terbang, hotel, dan visa) dinilai sebagai regulasi yang tumpul untuk dijadikan tuntunan karena ketimpangan penyelenggaraan umrah semakin marak dengan aksi manipulasi, penggelapan, pencucian bahkan pembodohan. Realisasi penyelenggaraan ibadah umrah berbasis maslahat yang tertuang dalam Peraturan Menteri Agama tersebut tidak seirama dengan qaidah fiqhiyyah:

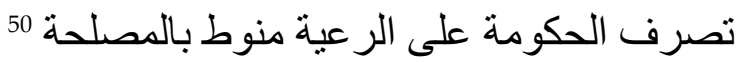

Artinya: Kebijakan pemerintah terhadap rakyatnya harus seiring dan berkaitan dengan kemaslahatan.

Keberadaan PMA Nomor 18 Tahun 2015 dinilai out of date (ketinggalan) dan menggunakan sistem manual. ${ }^{51}$ Kemaslahatan umum berbenturan dengan kepentingan biro travel "nakal" menjadi marak dan tidak terbendung dengan jumlah korban yang cukup fantastis. Perhatian publik kepada beberapa Penyelenggara Perjalanan Ibadah Umrah (PPIU) seperti First Travel, Solusi Balad Lumampuh (SBL), dan Abu Tour memiliki jumlah jemaah umrah yang fantastis. Jumlah jemaah umrah Abu Tour sebanyak 27.093 orang, SBL sebesar 12.845 orang dan First Travel yang memiliki jumlah jemaah umrah terbesar 72.682 orang. ${ }^{52}$

Majelis Ulama Indonesia dalam Musyawarah Nasional ke VII tahun 2005 dalam putusannya Nomor 6/MUNAS/VII/MUI/10/2005 merumuskan kemaslahatan hukum Islam dengan realisasi tujuan syariah (maqasid al-syari'ah) yang ditunjukkan dengan memenuhi terpeliharanya lima kebutuhan primer yaitu agama, jiwa, akal, keturunan dan harta..$^{53}$ Kemaslahatan seirama dengan syariah atau tidak bertentangan dengan dalil naqli. Penetapan atau ketetapan kemaslahatan ditentukan oleh lembaga yang secara sistem, struktur, kultur, formal dan kompetensinya diakui di bidang syariah dan dilakukan melalui ijtihad kolektif. ${ }^{54}$

${ }^{49}$ Lihat, A. Muchaddam Fahham, "Penyelenggaraan Ibadah Umrah: Akar Masalah dan Penanganannya", Info Singkat Kajian Singkat Terhadap Isu Aktual dan Strategis, Pusat Penelitian Badan Keahlian DPR RI Vol. X, No. 07/I/Puslit/April/2018, h. 13-17.

${ }^{50}$ Lihat, Djazuli, Kaidah-Kaidah FIkih, Kaidah-kaidah Hukum Islam dalam Menyelesaikan Masalahmasalah yang Praktis (Cet. III; Jakarta: Kencana Prenada Media, 2010), h. 147

${ }^{51}$ Mustolih Siradj, Investasi Bisnis Umrah dihambat Peraturan Menteri Agama, sebagai Ketua Komnas Haji dan Umrah diakses dan dikutip dari http://www.nu.or.id pada tanggal 12 Juni 2019.

${ }^{52}$ Lihat, A. Muchaddam Fahham, "Penyelenggaraan Ibadah Umrah: Akar Masalah dan Penanganannya", Info Singkat Kajian Singkat Terhadap Isu Aktual dan Strategis, Pusat Penelitian Badan Keahlian DPR RI Vol. X, No. 07/I/Puslit/April/2018, h. 13-17.

${ }^{53}$ Lihat, Felicitas Meta Maria Opwis, Maslaha and The Purpose of The Law: Studies in Islamic Law and Society (Boston Leiden: Martinus Nijhoff Publishers and VSP, 2010), h. 259.

${ }^{54}$ Lihat, Sekretariat Majelis Ulama Indonesia 2005, Himpunan Keputusan Musyawarah Nasional VII MUI tahun 2005, h. 156. 
Istislah mengindikasikan adanya nilai maslahat, potensi terwujudnya kemasla hatan atau minim dari celah mafsadah (hal-hal yang buruk). ${ }^{55}$ Menurut Syatibi di kalangan Mazhab Maliki bahwa istislah disinonimkan dengan istihsan dalam praktiknya. ${ }^{56}$ Eksistensi PMA Nomor 8 tahun 2018 adalah upaya untuk berbuat yang terbaik dan diakui kekuatannya dalam agama sehingga dinilai sarat dengan trik, cara dan terobosan yang lebih banyak mendatangkan kemaslahatan dan lebih menjauhkan kesulitan bagi umat. ${ }^{57}$ Muatan dalam peraturan menteri adalah peraturan perundang-undangan yang ditetapkan oleh menteri untuk menjalankan perintah peraturan perundang-undangan yang lebih tinggi yang ditentukan dalam undang-undangan, peraturan pemerintah, atau peraturan presiden. ${ }^{58}$

Kecenderungan penerapan istislah dalam PMA Nomor 8 tahun 2018 semakin kuat karena dimotivasi dari tantangan persoalan hukum yang berkembang dalam penyelenggaraan umrah yang semakin cepat berkembang dan semakin kompleks. ${ }^{59}$ Penggunaan maslahat dalam ijtihad regulasi tersebut menunjukkan sebuah kebijakan dibingkai dengan semangat nash yang bertujuan untuk meminimalisir maraknya anomali penyelenggaraan ibadah umrah. ${ }^{60}$ Dalam hierarki keilmuan Islam terdapat usul figh sebagai ilmu yang menggarap pondasi hukum Islam dan qawa'id fiqhiyyah sebagai pelebaran dari ilmu fikih dengan fungsi sentral dan marginal. Fungsi sentral karena memiliki cakupan luas dan dapat dipertimbangkan dalam menetapkan hukum. Fungsi marginalnya karena turunan kaidah dan cakupan yang terdapat di dalamnya dipersempit. ${ }^{61}$

Adanya nalar zari'ah atau upaya preventif ${ }^{62}$ (tanggap dan cegah dini) untuk meminimalisir penyimpangan dana jemaah baik dalam bentuk penipuan dan pencucian. Upaya mengeliminasi kesulitan dan penyimpangan dalam penyelenggaraan umrah yang dihadapi masyarakat Islam dilegitimasi oleh legal-

${ }^{55}$ Lihat, Khalid Ramadhan Hasan, Mu'jam Usul al Fiqh kita Yabhasu fi al Alfaz wa Mustalahat Ilmi Usul al Fiqh 'ala al Tartib al Abjadiy (Misr: Dar al Tarabisyi, 1418 H), h. 29. Lihat pula, Abdu al Wahhab al Khallaf, Ilmu Usul al Fiqh (Cet. XII; al-Qahirah: Dar al Qalam, 1979), h. 79.

${ }^{56}$ Lihat, Mahmud bin Zaid al Lamisyi al Hanafiy al Maturidy, Kitab fi Usul al Fiqh (Cet. I; Tunis: Dar al Garb al Islamiy, 1995), h. 370-377. Lihat, Amir Syarifuddin, Ushul Fiqh Jilid II (Cet. IV; Jakarta: Kencana Prenada Media Group, 2009), h. 333.

${ }^{57}$ Lihat, Mansur bin Muhammad bin 'Abdu al Jabbar al Sam'aniy, Qawati' al Adillah fi al Usul Juz al Tsani (Beirut: Dar al Kutub al Ilmiyyah, 1997 M/1418 H), h. 268. Lihat pula, Amir Syarifuddin, Ushul Fiqh Jilid II, h. 328.

${ }^{58}$ Lauddin Marsuni, Hukum Perundang-Undangan di Indonesia (Cet. I; Makassar: Libitera Institute, 2016), h. 38

${ }_{59}$ Lihat, Mansur bin Muhammad bin 'Abdu al Jabbar al Sam'aniy, Qawati' al Adillah fi al Usul Juz al Tsani, h. 268. Lihat, Amir Syarifuddin, Ushul Fiqh Jilid II, h. 341.

${ }^{60}$ Lihat, Amir Syarifuddin, Ushul Fiqh Jilid II, h. 359.

${ }^{61}$ Lihat, Jaih Mubarok, Kaidah Fiqh, Sejarah dan Kaidah Asasi (Jakarta: RajaGrafindo Persada, 2002), h. 17.

${ }^{62}$ Lihat, Wahbah al Zuhailiy, al Wajiz fi Usul al Fiqh (Suriah: Dar al Fikr, 1999), h. 86. Lihat, Abdu al Wahhab al Khallaf, Ilmu Usul al Fiqh, h. 202. 
source Imam al Hakim yang meriwayatkan dari Abi Sa'id al Khudri ra., dengan mengungkapkan pernyataan Nabi Muhammad saw dengan sabdanya ${ }^{63}$ :

$$
\text { لاضرر و لاضر ار ومن ضـار ضاره الله ومن شاق شاقه الله }
$$

Artinya: "Tidak boleh menyulitkan orang lain tidak pula dipersulit (orang lain); orang yang mempersulit orang lain akan dipersulit oleh Allah dan orang yang memusuhi orang lain akan dimusuhi Allah."

Eksistensi PMA Nomor 8 tahun 2018 tentang Penyelenggaraan Perjalanan Ibadah Umrah mengungkapkan kebijakan Menteri Agama yang didominasi dengan muatan represif dan kuratif. ${ }^{64}$ Keberadaan asosiasi travel umrah adalah penguatan sistem pelayanan dan regulasi, peningkatan kualitas pelayanan, mempermudah dalam memperjuangkan aspirasi biro penyelenggara haji dan umrah sehingga posisi tawarnya kepada pemerintah Saudi Arabia dapat ditangani karena disuarakan secara kolektif. ${ }^{65}$

Regulasi tersebut juga menutup celah adanya penambahan biaya yang diperlukan untuk pelaksanaan penyelenggaraan perjalanan ibadah umrah. ${ }^{66}$ Aksi menutup celah atau kemungkinan terjadinya manipulasi seirama dengan nalar zari'ah (preventif) dalam usul al figh. ${ }^{67}$ Bersifat kuratif atau memuat daya hukum yang dapat menangani masalah hukum jika calon jemaah berpotensi dirugikan atau calon jemaah diperhadapkan dengan persoalan hukum. ${ }^{68}$

Kedudukan PMA Nomor 8 tahun 2018 tersebut mempunyai kekuatan mengikat selama diperintahkan oleh Peraturan Perundang-undangan yang lebih tinggi atau dibentuk berdasarkan kewenangan sebagaimana disebutkan dalam Pasal 8 ayat (2) UU Nomor 12 Tahun 2011. Dengan demikian, eksistensi Peraturan Menteri Agama Nomor 8 tahun 2018 dibentuk atas dasar kewenangan termasuk dalam hal peraturan menteri. PMA tersebut terbentuk karena pendelegasian dari peraturan perundangundangan yang lebih tinggi atau dikenal secara teoritis sebagai peraturan kebijakan yang bersifat mengatur dan secara tidak langsung mengikat umum namun bukan peraturan perundang-undangan yang dapat diuji oleh Mahkamah Agung jika bertentangan dengan undang-undang. ${ }^{69}$

63 Ali Ahmad al Nadwi, al Qawa'id al Fiqhiyyah, Mafhumuha, Naasy'atuha, Tathawwuruha, Dirasat Mu'allifatiha, Adillatuha, muhimmatuha, Tathbiquha (Damaskus: Dar al Qalam, 1994), h. 288

${ }^{64}$ Lihat, Muhammad Hisyam al Burhaniy, Sadd al Zara'i' fi al Syari'ah al Islamiyyah (), h.

65 Lihat, Abdillah, Manajemen Umrah Mengurai Problematika Penyelenggaraan Ibadah Umrah di Indonesia, h. 20

${ }^{66}$ Lihat, Abdu al Hafiz al Sawi, Nazariyyatu al Zarai' wa Asaruha fi Tatbiqat al Mu'amalah al Maliyyah al Mu'asirah (Beirut: Dar al Fikr, t.th). Lihat pula, Pasal 1 ayat 5 dan 6, Bab II Pasal 9 ayat 1,2 dan 3 dalam Peraturan Menteri Agama Nomor 8 Tahun 2018 tentang Penyelenggaraan Perjalanan Ibadah Umrah diakses haji.kemenag.go.id pada tanggal 12 Juni 2019.

${ }^{67}$ Lihat, Abdu al Wahhab al Khallaf, Ilmu Usul al Fiqh, h. 84

${ }^{68}$ Lihat, Bab IV Pendaftaran dan Pembatalan dalam Pasal 11 ayat 1 - 11, Peraturan Menteri Agama Nomor 8 Tahun 2018 tentang Penyelenggaraan Perjalanan Ibadah Umrah diakses haji.kemenag.go.id pada tanggal 12 Juni 2019.

${ }^{69}$ Lihat, Mahfud MD, Politik Hukum di Indonesia (Cet. VI; Jakarta: RajaGrafindo Persada, 2014), h. 363 
Keberadaan PMA Nomor 8 tahun 2018 dikategorikan aturan kebijakan dengan jenis dan menurut hierarki peraturan perundang-undangan dan produk pemikiran hukum Islam mengenai penyelenggaraan ibadah umrah dilegitimasi secara yuridis normatif atau konstitusional menurut UUD 1945 pasal 29 ayat 1-2, UU Nomor 8 Tahun 1999 tentang Perlindungan Konsumen, dan Fatwa Ulama tentang umrah tahun 2012. Bahasa hukum yang dituangkan dalam regulasi PMA tersebut telah melalui interpretasi sistematis, historis, teleologis, antisipatoris dan modern. ${ }^{70}$

Rating PMA Nomor 8 tahun 2018 dikategorikan sebagai peraturan perundangundangan atas dasar delegasi (delegated legislation) dan dibentuk atas dasar kewenangan. Secara teoritik dikenal sebagai peraturan kebijakan namun bukan peraturan perundang-undangan sehingga tidak dapat diuji oleh Mahkamah Agung yang memiliki kewenangan menguji peraturan perundang-undangan di bawah undang-undang terhadap undang-undang. Kedudukan PMA Nomor 8 tahun 2018 setelah berlakunya UU Nomor 12 tahun 2011 baik atas dasar peraturan perundangundangan yang lebih tinggi maupun yang dibentuk atas dasar kewenangan berkualifikasi sebagai peraturan perundang-undangan. ${ }^{71}$

\section{E. SIMPULAN}

Sistem penyelenggaraan umrah seharusnya membawa berkah berubah menjadi bisnis umrah yang menggiurkan sehingga terjebak dalam rivalitas bisnis yang tidak syar'i. Tergerusnya beberapa oknum biro penyelenggara yang melakukan praktik money game, sistem ponzi, sistem berantai, model transaksi penyelenggaraan yang menuhankan nilai keuangan, mengkerdilkan atau menyudutkan nilai ketuhanan dan nilai kemanusiaan. Tagline yang diviralkan di berbagai media seperti manusia membantu manusia berubah menjadi manusia membinasakan manusia.

Dengan berbagai fenomena dan ketimpangan tersebut maka rancang bangun regulasi penyelenggaraan umrah perlu dilakukan secara terstruktur, sistematis dan masif dengan menggunakan mekanisme hukum. Pertimbangan dalam membenahi regulasi penyelenggaraan ibadah umrah dengan menggunakan mekanisme hukum terkesan mengalami kelambatan.

Penggunaan mekanisme hukum dalam merumuskan regulasi yang komprehensif meskipun terkesan lamban namun berdampak pada minimnya judicial review karena telah melalui nalar, dialog, cara, dan pergumulan akal dan nilai agama dalam menganalisa suatu masalah. Hierarki PMA Nomor 8 tahun 2018 menjadi UU Nomor 8 tahun 2019 tentang Penyelenggaraan Haji dan Umrah bukan sekedar aturan kebijakan, aturan perundang-undangan tapi juga memiliki kekuatan hukum yang mengikat.

\footnotetext{
${ }^{70}$ Lihat, Peter Mahmud Marzuki, Penelitian Hukum, h. 147.

${ }^{71}$ Lihat, Bilal Dewansyah, Kedudukan Peraturan Menteri dalam Hierarki Peraturan Perundangundangan, diakses hukumonline.com pada tanggal 20 Juni 2019.
} 


\section{Daftar Pustaka}

Abdillah, Manajemen Umrah Mengurai Problematika Penyelenggaraan Ibadah Umrah di Indonesia. Cet. I; Makassar: Penerbit Shofia, 2018.

al-'Aqqad, Abbas Mahmud. al Islam Da'wah 'Alamiyyah. al-Qahirah: Maktabah al Usrah, 1999.

Ali, Zainuddin Sosiologi Hukum. Cet. VII; Jakarta: SInar Grafika, 2012.

Amphuri, Profil mengenai Asosiasi Muslim Penyelenggara Haji dan Umrah Republik Indonesia, diakses via amphuri.org pada tanggal 21 Mei 2019.

Apeidom, Van. Inleiding Tot de Stude Van Het Nederlandse Recht, diterjemahkan oleh M. Oetarid Sadino dengan judul: Pengantar Ilmu Hukum. Jakarta: NoordhoffKolff, 1959.

Arif, Firman Muhammad. "Penyelenggaraan Ibadah Umrah Berbasis Maslahat", alAmwal Edisi Maret Nomor 1 Tahun 2019.

Asshiddiqie, Jimly Pengantar Ilmu Hukum Nata Negara Jilid I. Jakarta: Penerbit Sekretariat Jendral dan Kepanitian MK RI, 2006.

Black, Donald. Sociological Justice. New York: Academic Press, 1989

Dani, Akhmad Anwar. "Problematika Pengelolaan Penyelenggaraan Umrah di Kota Surakarta", Ilmu Dakwah: Academic Journal for Homiletic Studies Volume 12 Nomor 1, 2018 UIN Sunan Gunung Djati.

Dewan Syariah Nasional MUI. Himpunan Fatwa DSN MUI, Keputusan Nomor 28/DSNMUI/III/2002, diterbitkan atas kerjasama MUI dengan Bank Indonesia, Edisi II, tahun 2002.

Dewansyah, Bilal. Kedudukan Peraturan Menteri dalam Hierarki Peraturan Perundangundangan, diakses hukumonline.com pada tanggal 20 Juni 2019.

Dewi, Subkhani Kusuma. “Trend Wisata Umrah: Antara Meneladani Sunnah dan Turisme Spiritual", Empirisma Volume 26 Nomor 2 Juli Tahun 2017

Djazuli. Kaidah-Kaidah Fikih-Kaidah-Kaidah Hukum Islam dalam Menyelesaikan Masalahmasalah yang Praktis. Cet. III; Jakarta: Kencana Prenada Media, 2010.

Dirjen Penyelenggaraan Haji dan Umrah Kementerian Agama RI, UU Nomor 34 Tahun 2014 tentang Pengelolaan Keuangan Haji, diakses haji.kemenag.go.id pada tanggal 12 Juni 2019.

Dirjen Penyelenggaraan Haji dan Umrah Kementerian Agama RI, Peraturan Menteri Agama Nomor 18 Tahun 2015 Pasal 1 tentang Penyelenggaraan Perjalanan Ibadah Umrah, diakses haji.kemenag.go.id pada tanggal 25 Juni 2019.

Dirjen Penyelenggaraan Haji dan Umrah Kementerian Agama RI, UU Nomor 8 Tahun 2019 tentang Penyelenggaran Ibadah Haji dan Umrah, diakses haji.kemenag.go.id pada tanggal 12 Juni 2019. 
Dirjen Penyelenggaraan Haji dan Umrah Kementerian Agama RI, Tingginya Minat Umrah, Kemenag Ingatkan 5 Pasti Umrah ke Publik, diakses haji.kemenag.go.id pada tanggal 12 Juni 2019.

Fahham, A. Muchaddam. “Penyelenggaraan Ibadah Umrah: Akar Masalah dan Penanganannya", Info Singkat Kajian Singkat Terhadap Isu Aktual dan Strategis, Pusat Penelitian Badan Keahlian DPR RI Vol. X, Nomor 07/I/Puslit/April/2018.

Gunawan. Dicatut Penipu, Direktur Biro Travel Haji dan Umrah Merugi 500 jutaan, diakses news.detik.com pada tanggal 17 Mei 2019.

Hanifan. Aqwam Fiazmi. Komersialisasi Umrah Ketika Ibadah Bernilai Bisnis, diakses dari komersialisasi-umrah-ketika-ibadah-bernilai-bisnis-Dl pada tanggal 17 April 2019.

Harahap, Sumuran Lintasan Haji Indonesia. Jakarta: Intermedia, 1994.

Hasan, Khalid Ramadhan. Mu'jam Usul al Figh kita Yabhasu fi al Alfaz wa Mustalahat Ilmi Usul al Figh 'ala al Tartib al Abjadiy. Misr: Dar al Tarabisyi, 1418 H.

Hermawan, Kartajaya. \& Sula Muhammad Syakir, Syariah Marketing. Bandung: PT Mizan Pustaka, 2006.

Himpuh, Profil mengenai Himpunan Penyelenggara Umrah dan Haji Khusus, diakses via himpuh.or.id pada tanggal 21 Mei 2019.

I Nyoma Prabu Buana Rumiartha, "Kedudukan Peraturan Menteri pada Konstitusi", Majalah Ilmiah Widyasrama Universitas Dwijendra Denpasar 2011.

al Khallaf, Abdu al Wahhab Ilmu Usul al Figh (Cet. XII; al-Qahirah: Dar al Qalam, 1979.

Kementerian Agama. PP Nomor 79 tahu 2012 tentang Penyelenggaraan Ibadah Haji.

Kementerian Agama RI, PMA Nomor 396 Tahun 2003 tentang Penyelenggaraan Ibadah Haji dan Umrah.

Kementerian Agama, PMA Nomor 18 Tahun 2015 tentang Penyelenggaraan Perjalanan Ibadah Umrah.

Kesthuri, Profil Kesatuan Tour Travel Haji Umrah Republik Indonesia, diakses kesthuri.id pada tanggal 21 Mei 2019.

Kholilirrahman. "Hajinya Lansia Ditinjau dari Perspektif Bimbingan dan Konseling Islam", Jurnal al-Balagh Jurnal Dakwah dan Komunikasi IAIN Surakarta Volume 2 No. 2, Juli - Desember 2017.

Mahfud MD. Politik Hukum di Indonesia. Cet. VI; Jakarta: RajaGrafindo Persada, 2014.

Marzuki, Peter Mahmud. Penelitian Hukum. Cet. VIII; Jakarta: Kencana Prenada Media Group, 2013.

Marsuni, Lauddin. Hukum Perundang-Undangan di Indonesia Cet. I; Makassar: Libitera Institute, 2016.

al Maturidy, Mahmud bin Zaid al Lamisyi al Hanafiy. Kitab fi Usul al Figh (Cet. I; Tunis: Dar al Garb al Islamiy, 1995 
Misbakhun. OJK Larang Masyarakat Cicil Biaya Umrah di Travel, diakses OJK.go.id pada tanggal 10 Juni 2019.

Mubarok, Jaih Kaidah Fiqh, Sejarah dan Kaidah Asasi. Jakarta: RajaGrafindo Persada, 2002.

al Nadwi, Ali Ahmad al Qawa'id al Fiqhiyyah, Mafhumuha, Naasy'atuha, Tathawwuruha, Dirasat Mu'allifatiha, Adillatuha, muhimmatuha, Tathbiquha. Damaskus: Dar al Qalam, 1994.

Opwis, Felicitas Meta Maria. Maslaha and The Purpose of The Law: Studies in Islamic Law and Society. Boston Leiden: Martinus Nijhoff Publishers and VSP, 2010.

PT. Budi Luhur Abadi, 6 Asosiasi Penyelenggara Haji dan Umrah di Indonesia, diakses via ayohaji.com pada tanggal 21 Mei 2019.

Prihanto, Sigit. "Penegakan Hukum terhadap Tindak Pidana Penipuan Calon Jamaah Umrah", Jurnal Hukum Khaira Ummah Vol. 12 No. 4 Desember 2017.

Rangkuti, Affan. Industri Umrah Berpotensi Sumbang 7,2 Triliun, diakses via republika.co.id pada tanggal 17 April 2019.

Ratnawati, Novi “Upaya Penanggulangan Terjadinya Penipuan yang Dilakukan Biro Perjalanan Umrah: Studi Kasus Kota Bandar Lampung", Jurnal Hukum Fak. Hukum Universitas Lampung di Bandar Lampung Vol. I No. 1 Tahun 2018.

Redaksi Republika, Pengelolaan Haji pada Masa Orde Lama, diakses republika.co.id pada tanggal 17 Mei 2019.

Republik Indonesia, Undang-Undang Nomor 13 Tahun 2008 tentang Penyelenggaraan Ibadah Haji.

Republik Indonesia, Undang Undang Nomor 17 Tahun 1999 tentang Penyelenggaraan Ibadah Haji.

Sabiq, Sayyid. Figh al Sunnah Mujallad al Awwal. al-Qahirah: Dar al-Fath li al-I'lam al'Arabiy, 1998 M/1417 H

Saifuddin, Lukman Hakim. Kemenag Ungkap Penyebab Penipuan Umrah Marak di 6 Tahun Terakhir, diakses detik.com pada tanggal 19 Mei 2019.

al Sam'aniy, Mansur bin Muhammad bin 'Abdu al Jabbar. Qawati' al Adillah fi al Usul Juz al Tsani. Beirut: Dar al Kutub al Ilmiyyah, 1997 M/1418 H

Sali, Mahrus. Catatan Penyelenggaraan haji dari Masa ke Masa, artikel online diakses iphi.web.id pada tanggal 17 Mei 2019

Sari, Indah Fitriana. "Tinjauan Hukum Islam terhadap Pembiayaan Haji dan Umrah Melalaui Sistem Marketing di PT. Arminareka Perdana Yogyakarta", Jurnal Economic: Ekonomi dan Hukum Islam Vol. 5 No. 1 tahun 2015.

al Sawi, Abdu al Hafiz. Nazariyyatu al Zarai' wa Asaruha fi Tatbiqat al Mu'amalah al Maliyyah al Mu'asirah. Beirut: Dar al Fikr, t.th.

Sekretariat Majelis Ulama Indonesia 2005, Himpunan Keputusan Musyawarah Nasional VII MUI tahun 2005. 
Siradj, Mustolih Investasi Bisnis Umrah dihambat Peraturan Menteri Agama, sebagai Ketua Komnas Haji dan Umrah diakses dan dikutip dari http://www.nu.or.id pada tanggal 12 Juni 2019.

al Syahid, al Sayyid. al Khitab al Islamiy wa al 'Adalah bi al Akhar. al Qahirah; Wizarah al Awqaf Misr, 1423 H/2002 M.

Syahrani, Riduan. Intisari Ilmu Hukum. Cet. VI; Bandung: Citra Aditya Bakti, 2013.

Syarifuddin, Amir. Ushul Fiqh Jilid II Cet. IV; Jakarta: Kencana Prenada Media Group, 2009.

al Shirazy, Habiburrahman. Alasan Umrah Plus Wisata Halal Makin Berkembang, diakses republika.co.id pada tanggal 21 April 2019.

Sulaiman, Fajar. Pemahaman tentang Literasi Keuangan, diakses via wartaekonomi.co.id pada tanggal 11 Juni 2019.

Tim Jurnalis Detik.com, Fakta-fakta Mengejutkan dalam Persidangan CEO Abu Tours, diakses https://news.detik.com/ pada tanggal 21 April 2019.

Weruin, Urbanus Ura. "Logika, Penalaran, Argumentasi Hukum", Jurnal Konstitusi Volume 14 Nomor 2, Juni 2017.

al Zuhailiy, Wahbah. al Wajiz fi Usul al Fiqh. Suriah: Dar al Fikr, 1999 